\title{
Productivity of Intensively Managed Pastures of Five Grasses on Steep Slopes in the Humid Mountains of Puerto Rico ${ }^{1}$
}

\author{
Rubén Caro Costas, José Vicente Chandler, and Jacinto Figarella ${ }^{2}$
}

\section{INTRODUCTION}

Although there is considerable information on the productivity of pastures in the coastal regions of Puerto Rico [Rivera-Brenes et al. $\left(5,^{3} 6\right)$, and Caro-Costas et al. (4)], little is known about the carrying capacity and beef yields which can be expected of pastures on steep slopes in the Humid Mountain Region where lies the greatest potential for livestock production on the Island. Vicente-Chandler et al. (7), found that lightly fertilized kudzu-molasses grass pastures on 50-percent slopes in this region carried 1 head and produced 500 pounds of beef per acre yearly over 10 consecutive years. Caro-Costas and Vicente-Chandler $(8)$ found that Napier grass pastures on steep slopes in this region produced 570 and 1,072 pounds of beef per acre yearly when fertilized with 600 and 1,800 pounds of 14-4-10 fertilizer per acre yearly, respectively. Increasing fertilization to 3,000 pounds per acre did not further increase yields.

The purpose of the present study was to determine the productivity, in terms of carrying capacity and of beef yields, of intensively managed, wellfertilized pastures of Pangola, Guinea, Napier, Para, and molasses grasses on steep slopes under typical conditions in the Humid Mountain Region of Puerto Rico over a 4-year period.

\section{MATERIALS AND METHODS}

The experiment was carried out near Orocovis, at an elevation of about 2,000 feet, with mean annual temperature of about $75^{\circ} \mathrm{F}$., and a seasonal variation of less than $10^{\circ} \mathrm{F}$. The soil type is Cialitos clay, a deep, red, latosol typical of the Mountain Region, with an average slope of 45 percent. The surface 6 inches of soil at the start of the experiment had 3.9 percent of organic matter; a $\mathrm{pH}$ of $4.9 ; 16.2$ meq. of exchange capacity, and 8.2 meq.

1 This work was carried out cooperatively between the Soil and Water Conservation Research Division, Agricultural Research Service, USDA, and the Agricultural Experiment Station, University of Puerto Rico, Río Piedras, P.R.

${ }^{2}$ Agronomist (cooperative between the agencies mentioned in footnote 1), Project Supervisor, and Chemist, Soil and Water Conservation Research Division, Agricultural Research Service, USDA, respectively, stationed at the Agricultural Experiment Station, University of Puerto Rico, Río Piedras, P.R.

${ }^{3}$ Italic numbers in parentheses refer to Literature Cited, p. 111. 
of exchangeable bases per $100 \mathrm{gm}$. of soil; and a bulk density of 1 , with 12 percent of the pores drained at a tension of $60 \mathrm{~cm}$. of water.

Three 1-acre pastures were planted to each of the five grasses in a randomized-block design. The pastures, rectangular in shape, extended from the top of a ridge where shade and salt blocks were available, down to a small creek with abundant water. The soil in all 15 pastures was limed to about $\mathrm{pH}$ 6.0, and 1 ton of 14-4-10 fertilizer was applied per acre yearly in 4 equal applications at 3 -month intervals.

The pastures were grazed by young cattle initially weighing about 350 pounds and replaced yearly. The cattle, treated periodically for parasites and otherwise well cared for, received no feed other than that obtained from the pastures. Holstein heifers were used during the first 3 years and bulls, implanted with $24 \mathrm{mg}$. of Dieth Stilbestrol every 6 months, were used during 1962. The "tester" cattle, which were to remain on the pastures for a full year, were divided into five groups, one for each grass. Two testers were kept per acre at all times on the Pangola, Guinea, and Napier grass pastures and $11 / 3$ head per acre on the Para and molassesgrass pastures. Additional animals were added to each group as required to consume excess forage produced during seasons of flush growth using the well-known "takeand-put" method.

Cattle were moved from one pasture to another of the same grass when essentially all the leaves had been eaten from the stalks of Napier grass (fig. 1,A); when Guinea grass clumps had been grazed down to a height of 8 to 12 inches (fig. 1,B); when Pangola grass herbage had been grazed down to a height of about 4 inches (fig. 1,C); and when molassesgrass and Para grass herbage had been grazed down to a height of 6 to 8 inches. On the average, the pastures were grazed for 11 days followed by a 22-day rest period.

Cattle were weighed each time they were moved from one enclosure to another and a record was kept of grazing days, animal weights, and gains in weight for each pasture. The total digestible nutrients produced by each pasture were calculated from these data following recommendation of the Pasture Research Committee (1). Carrying capacities were calculated from these data and are expressed in terms of 600-pound steers. ${ }^{4}$

During 1960 and 1962, six 1-square-yard areas in each pasture of Pangola Guinea, and Napier grasses were mowed before, and another six after, each grazing, and weight and protein content of the forage were determined. From these data, the amount and protein content of the forage actually consumed by the livestock were calculated by difference. New

1 One 600 -lb. steer gaining normally in weight requires $8.5 \mathrm{lb}$. of total digestable nutrients daily (Q). 
areas were used in each grazing round so as to reflect trampling and grazing effects. In addition, forage samples obtained by plucking so as to simulate grazing were taken before each grazing period from six areas in each pasture during 1962. The samples, approximately representing the forage consumed by the cattle, were analyzed for protein, phosphorus, calcium, and lignin.

Possible compaction of the surface soil from trampling and its effect on forage yields were determined in pastures of Pangola, Guinea, and Napier grasses after 4 years of intensive grazing. Bulk density and volume of pores drained at a tension of $60 \mathrm{~cm}$. of water were determined in six undisturbed cores, 4 inches in diameter, taken from the surface 3 inches of soil in pastures of these grasses at start of the experiment and again 4 years later. At this time also an experiment was carried out in one pasture of each of theses grasses to determine the effect of loosening the surface soil on subsequent yields of forage at two levels of fertility, 0 and 1 ton of 14-4-10 fertilizer per acre yearly. All treatments were replicated four times with each grass using a split-plot design with fertility levels as the main plots and tillage levels as the subplots, which were $10 \times 10$ feet in size. The soil in the tilled plots was loosened to a depth of 4 inches without turning the sod, while that in other plots was not disturbed. Fertilizer was applied to the soil surface. Yields of green forage produced 40 days after treatment and again $\mathbf{9 0}$ days after treatment were determined.

\section{RESULTS AND DISCUSSION}

Rainfall during the 4 years of experimentation (1959 through 1962) averaged 62.9 inches yearly with a low of 49.4 inches in 1961 , and a high of 75.8 in 1962. January, February, and March were the driest months, averaging only 3.4 inches of rainfall compared to 6.3 monthly for the remainder of the year.

Para grass and molassesgrass produced significantly lower gains in weight, an average of 6336 pounds per acre ycarly, less total digestible nutrients, and had a lower carrying capacity, 1.6 (600-pound stecrs per acre, than Pangola, Guinca, or Napier grasses (tables 1 and 2). Only 1//3 head were kept per acre on the Para grass and molassesgrass pastures during 196(i1, since they appeared incapable of carrying the 2 head per acre established as a minimum for the other three grasses. At this relatively low rate of stocking, cattle made acceptable daily gains on both grasses, but per-acre yeilds were low, and the stand of molassesgrass was so seriously depleted that this grass was thereafter onitted from the experiment. During 196(i2, when pressure was increased on the Para grass pastures by keeping 22 head per acre throughout the year, daily gains dropped sharply (table 1), per- 

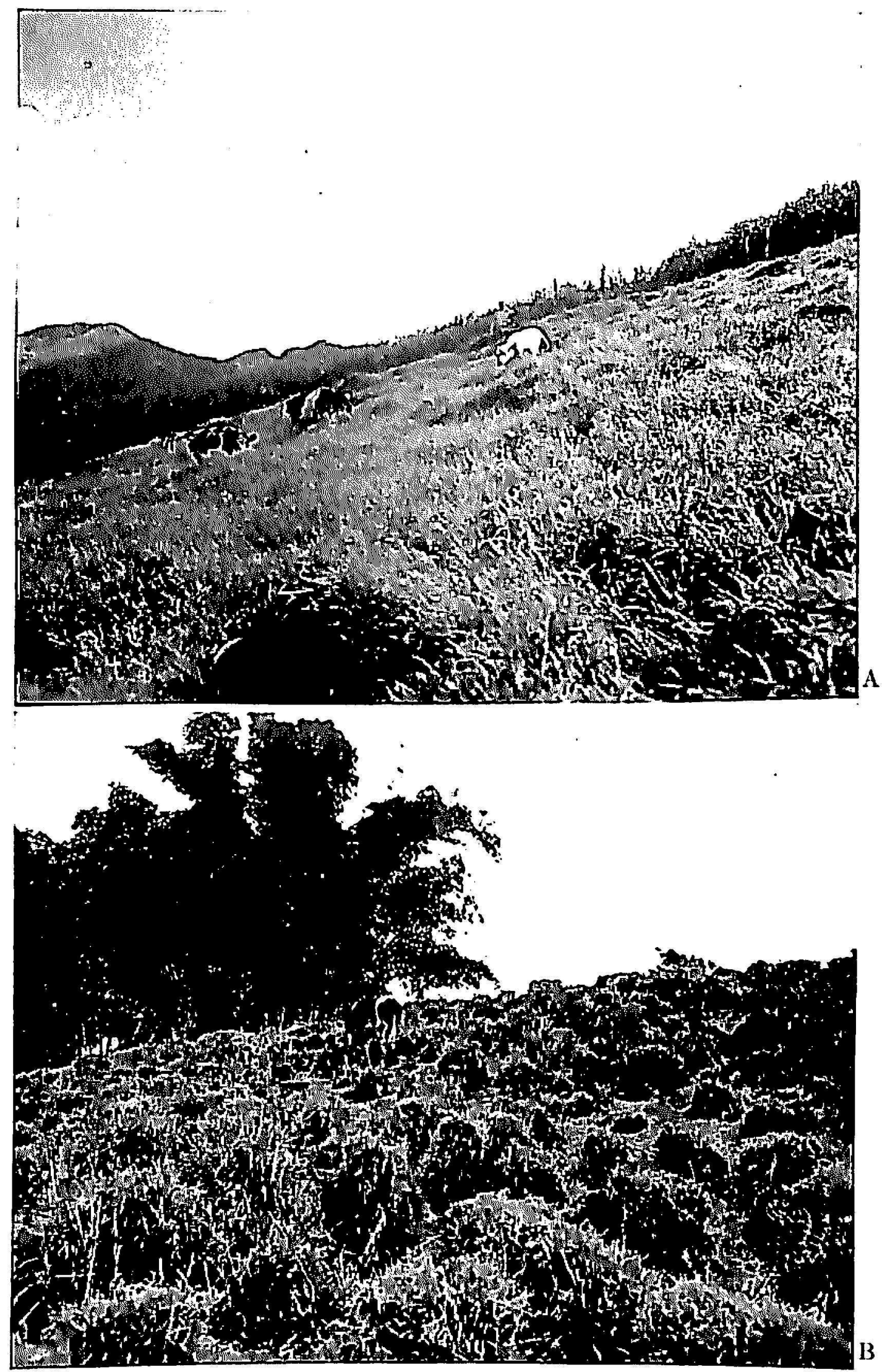

FI(i. 1. -Cattle grazing the intensively managed experimental pastures of: A, Pangola, B, (iuinea, and C, Napier grasses near Orocovis. These pastures, receiving $1 \mathrm{ton}$ of 14-4-10 fertilizer per acre yearly, produced an average of over 1,000 pounds of beef per acre yearly over a 4-year period. Note difference in growth habit of the various grasses under grazing management and excellent condition of bulls (I)) fed exclusively on pastures. 


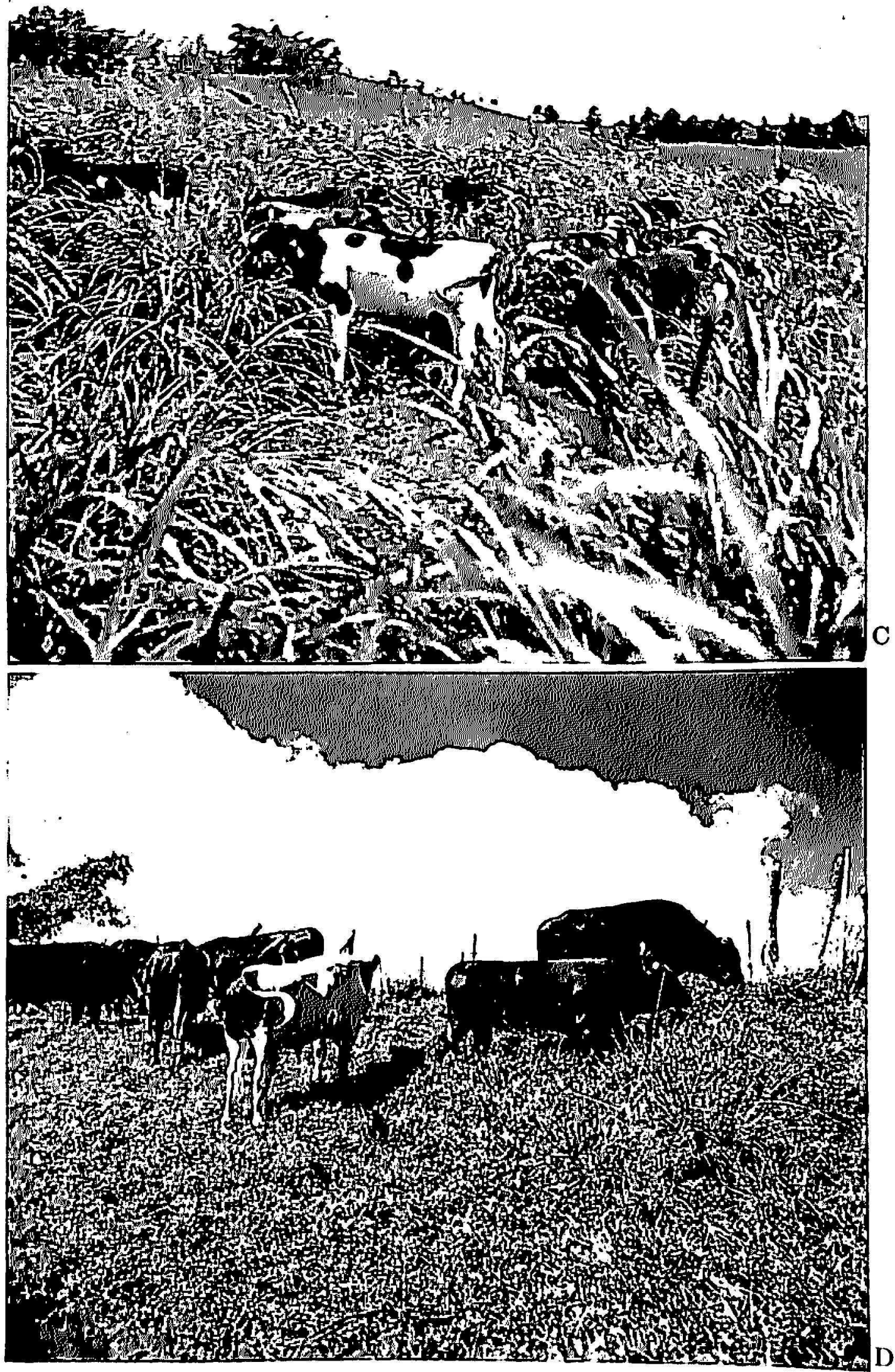

Fi(i. 1 C-1) 
TABLE 1.-Beef produced (pounds) by inlensively managed, well-fertilized pastures of 5 grasses growing on stecp slopes over a 4-year period at Orocovis, 1959-62

\begin{tabular}{|c|c|c|c|c|c|}
\hline \multirow{2}{*}{ Grass } & \multicolumn{5}{|c|}{ Gains in weight per acre yearlyl. : } \\
\hline & 1959 & 1960 & 1961 & 1962 & Average \\
\hline Pangola & $910(1.2)$ & $302(1.2)$ & $943(1.1)$ & $1,262(1.5)$ & $1,004(1.25)$ \\
\hline Guinen & $1,186(1.5)$ & $1,152(1.3)$ & $983(1.1)$ & $1,389(1.4)$ & $1,178(1.30)$ \\
\hline Napier & $990(1.3)$ & $\varepsilon 91 \quad(1.3)$ & $945(1.1)$ & $1,138(1.3)$ & $991 \quad(1.25)$ \\
\hline Para & - & - & $652(1.2)$ & $742 \quad(.9)$ & $(697(1.05)$ \\
\hline Molasses & - & - & $575(1.0)$ & - & $575(1.00)$ \\
\hline Average $^{3}$ & $1,029(1.3)$ & $982 \quad(1.3)$ & $957(1.1)$ & $1,263(1.4)$ & $1,058(1.3)$ \\
\hline L.S.D. $\begin{array}{l}05 \\
01\end{array}$ & N.S. & N.S. & $\begin{array}{l}220 \\
306\end{array}$ & $\begin{array}{l}267 \\
389\end{array}$ & - \\
\hline $\begin{array}{l}\text { Annual } \\
\text { (inches) }\end{array}$ & 57.4 & 68.9 & 49.4 & 75.8 & 62.9 \\
\hline
\end{tabular}

'Holstein heifers for first 3 years, scrub bulls implanted with Dieth Stilbestrol during 1962.

2 Numbers in parentheses show average daily gains in pounds for animals grazed for a full year.

${ }^{3}$ For first 3 grasses only.

TABLE 2.-T'olal digestible nulrients' (pounds) produced by inlensively managed, well-fertilized pastures of 5 grasses growing on sleep slopes over a 4-year period al Orocovis, $1959-62$

\begin{tabular}{|c|c|c|c|c|c|}
\hline \multirow{2}{*}{ Grass } & \multicolumn{5}{|c|}{ Total digestible nutrients per acre yearly= } \\
\hline & $195 \%$ & $1 \% 0$ & 1961 & 1962 & Average \\
\hline Pangola & $7,220(2.3)$ & $(0.340(2.1)$ & $7,020(2.3)$ & $9,120(2.9)$ & $7.425 \quad(2.4)$ \\
\hline Ciuinea & $7,1,50 \quad(2.5)$ & $7,740(2.5)$ & $(i, 980(2.3)$ & 9,$51 ; 0 \quad(3.1)$ & $7,98: 3 \quad(2.6)$ \\
\hline Napier & $(i, 810 \quad(2.2)$ & $(i, 3 \mathcal{E} 0(2.1)$ & 7,0 i0 $(2.3)$ & $8,820(2.8)$ & $7,2(i 8 \quad(2.4)$ \\
\hline Para & - & - & $4,7100(1.5)$ & $(\mathbf{i}, 730 \quad(2.2)$ & $5,745(1.8)$ \\
\hline Molasses & - & - & $4.320(1.4)$ & - & $4,320(1.4)$ \\
\hline Average $^{3}$ & $7,227(2.3)$ & $(i, 82() \quad 2.2)$ & $7,020(2.3)$ & $9,167(2.9)$ & $7,559(2.5)$ \\
\hline I..S.I). 05 & N.S. & NA. & $\begin{array}{r}935 \\
1,2 i 7\end{array}$ & $\begin{array}{r}911 \\
1,023\end{array}$ & - \\
\hline
\end{tabular}

1 Calculated from hody-weights, days of grazing, and gains in weight following recommendations of the Pasture Research Committee (1).

2 Numbers in parentheses show earrying capacity in terms of $600-1 b$. steers.

3 For first 3 grasses only. 
acre gains remained low, and stand was depleted. Since it is evident that both Para grass and molassesgrass are inferior to Pangola, Guinea, and Napier grasses, the remaining discussion is limited to the latter three.

An almost perfect stand of Pangola, Guinea, and Napier grasses was maintained throughout the experiment, and there was no problem with weeds, which seemed incapable of invading these well-managed pastures. Guinea grass clumps and uneaten Napier grass stalks (fig. 1) were cut back with machetes once a year, using 3 man-days of labor per acre. Pangola grass was at times rather severely attacked by the yellow sugarcane aphid (Sipha flava), but the other grasses were not affected. There was little fouling and no evidence of "manure spots" in these pastures, probably because of the high rate of fertilization which kept all the grass growing at close to maximum rates.

TABLE 3.-Average forage consumption by catlle on Pangola, Guinea, and Napier grass pastures, Orocovis, 1960-62

\begin{tabular}{|c|c|c|}
\hline Grass & $\begin{array}{l}\text { Dry forage consumed per acre } \\
\text { yearly by cattle }\end{array}$ & $\begin{array}{l}\text { Average protein content of } \\
\text { forage consumed }\end{array}$ \\
\hline $\begin{array}{l}\text { Pangola } \\
\text { Guinea } \\
\text { Napier }\end{array}$ & $\begin{array}{l}\text { Pounds } \\
11,950 \\
14,570 \\
15,800\end{array}$ & $\begin{array}{c}\text { Percent } \\
18.3 \\
15.5 \\
16.6\end{array}$ \\
\hline Average & 14,107 & 16.8 \\
\hline
\end{tabular}

Pangola, Guinea, and Napier grasses produced similar yields, averaging 1,058 pounds of gain in weight (table 1 ) and 7,559 pounds of total digestible nutrients per acre yearly (table 2), with an average carrying capacity of 2.5600 -pound steers per acre. There were no significant differences in gains in weight or carrying capacity of these grasses during any of the 4 years of experimentation (tables 1 and 2). Productivity of the pastures varied little from year to year, except in 1962 when all grasses yielded more, probably because of the higher rainfall and the use of bulls implanted with Dieth Stilbestrol, instead of the slower-gaining dairy heifers used during previous years. Overall daily gains per head for "tester" cattle grazed for a full year averaged 1.2 pounds for heifers and 1.4 pounds for bulls (table 1) which is considered good for young animals of this type fed exclusively on pastures.

Table 3 shows that, as with gains in weight and total digestible nutrients, there was no significant difference in the amount or protein content of forage consumed by cattle grazing these three grasses. An average of 7.2 pounds of total digestible nutrients, or 12.6 pounds of dry forage actually 
consumed by the cattle, were required to produce a pound of beef. Consumption of forage by the cattle as determined by this method checks well with calculations based on a normal consumption of dry forage of 2.5 percent of body-weight. Since the average weight of the cattle while on the pastures was about 600 pounds, and 2.5 head were carried per acre, dryforage consumption should be about 13,688 pounds per acre yearly; the 14,107 pounds determined by the difference method compares closely with this.

Season of the year had a strong influence on total digestible-nutrient production, and all of the grasses were affected similarly (table 4). Production was lowest during the "winter" months of November through February, followed by considerably higher yields from March through June, with highest production during the months of heaviest rainfall, July through October.

TABLE 4.-Seasonal tolal digestible-nutrient production (pounds) of 3 grasses at Orocovis during 1962

\begin{tabular}{l|c|c|c|c}
\hline \multicolumn{1}{c|}{ Months } & Pangola & Guinea & Napier & Average \\
\cline { 1 - 2 } \cline { 5 - 5 } November through February & 2,520 & 2,210 & 2,150 & 2,293 \\
March through June & 3,130 & 3,330 & 3,000 & 3,153 \\
July through October & 3,470 & 4,020 & 3,670 & 3,720 \\
\cline { 2 - 3 } Total & 9,120 & 9,560 & 8,820 & 9,166 \\
\hline
\end{tabular}

Quality of the forage consumed by the grazing cattle was excellent. Compositions of Pangola, Guinea, and Napier grass forage obtained by plucking so as to simulate grazing were surprisingly similar and varied little with season of the year (table 5), probably because of the fairly uniform rainfall and frequent fertilization which maintained an even supply of nutrients at all times.

Crude-protein content of the forage was similarly high with all three grasses, averaging 18.1 percent, and varied little with season of the year (table 5). This estimate of the protein content of the forage consumed by cattle checks rather well with that obtained by the difference method shown in table 3. Phosphorus content of the forage was also similar for all grasses, averaging 0.22 percent, and generally varied little with season of the year. Lignin content of the forage generally varied little with season of the year and was similar for all grasses, averaging $8.99,7.63$, and 7.77 percent for Pangola, Guinea, and Napier grasses, respectively (table 5). Guinea grass contained about twice as much calcium (0.62 percent) as did Pangola or Napier grasses. 
Table 6 shows that intensive grazing over a 4-year period had little effect on physical condition of the surface soil which remained excellent under all three grasses, as shown by the low bulk densities and high proportion of large pores.

TABLE 5.-Dry-weight composition (percenl) of forage of 3 well-ferlitized grasses at Orocovis ${ }^{1}$ during 1962

\begin{tabular}{|c|c|c|c|c|c|c|c|c|c|c|c|c|}
\hline \multirow{2}{*}{ Months } & \multicolumn{4}{|c|}{ Pangola } & \multicolumn{4}{|c|}{ Guinea } & \multicolumn{4}{|c|}{ Napier } \\
\hline & Protein & Lignin & $\mathrm{Ca}$ & $\mathbf{P}$ & Protein & Lignin & $\mathrm{Ca}$ & $\mathbf{P}$ & Protein & Lignin & $\mathrm{Ca}$ & $\mathbf{P}$ \\
\hline Jan.-Feb. & 18.1 & 9.39 & 0.32 & 0.19 & 19.8 & 7.18 & $|0.67|$ & $|0.19|$ & 20.7 & 7.20 & 0.30 & 0.20 \\
\hline Mar.-Apr. & 16.4 & 9.02 & .33 & .20 & 17.5 & 7.73 & .67 & .23 & 18.6 & 7.90 & .30 & .25 \\
\hline May-June & 14.9 & 7.95 & .35 & .21 & 16.8 & 7.78 & .65 & .23 & 16.8 & 8.02 & .29 & .25 \\
\hline July-Aug. & 16.7 & 8.93 & .35 & .18 & 16.6 & 7.62 & .60 & .20 & 18.7 & 7.68 & .29 & .24 \\
\hline Sept.-Oct. & 18.3 & 7.20 & .35 & .25 & 18.9 & 8.30 & .53 & .21 & 20.0 & 7.73 & .28 & .25 \\
\hline Nov.-Dec. & 17.3 & 11.45 & .37 & .20 & 19.5 & 7.16 & .58 & .21 & 20.9 & 8.10 & .30 & .25 \\
\hline Average & 16.9 & 8.99 & 0.35 & 0.21 & 18.2 & 7.63 & 0.62 & 0.21 & 19.3 & 7.77 & 0.29 & 0.24 \\
\hline
\end{tabular}

- Values shown are averages of 36 samples-6 samples taken at intervals of 10 days over a 2 -month period, by plucking so as to simulate grazing.

TABLE 6.-Effects of inlensive grazing of 3 grasses over a 4-year period on condition of the surface soil at Orocovis

\begin{tabular}{|c|c|c|}
\hline \multirow{2}{*}{ Pasture } & \multicolumn{2}{|c|}{ Data for soil characteristics ${ }^{2}$} \\
\hline & Bulk density & $\begin{array}{l}\text { Volume of pores } \\
\text { drained at a tension } \\
\text { of } 60 \mathrm{~cm} \text {. of water }\end{array}$ \\
\hline & & Percen! \\
\hline \multicolumn{3}{|l|}{ Pangola: } \\
\hline Initially. $\ldots \ldots \ldots \ldots \ldots \ldots \ldots \ldots \ldots$ & 1.04 & 12.2 \\
\hline After 4 years of grazing..$\ldots \ldots \ldots$ & 1.08 & 11.5 \\
\hline \multicolumn{3}{|l|}{ Guinea: } \\
\hline$\cdots \ldots \cdots \cdots \cdots \cdots \cdots \cdots \cdots$ & 1.00 & 13.3 \\
\hline After 4 years of grazing..$\ldots \ldots \ldots \ldots$ & 1.11 & 14.1 \\
\hline \multicolumn{3}{|l|}{ Napier: } \\
\hline Initially $\ldots \ldots \ldots \ldots \ldots \ldots$ & 1.05 & 10.0 \\
\hline After 4 years of grazing . . . . . . & .95 & 11.4 \\
\hline
\end{tabular}

1 Available moisture, that retained at pressures between $1 / 3$ and 15 atm., averaged 10.4 percent, or $1.3 \mathrm{in} . / \mathrm{ft}$. of soil. All values are averages of 6 undisturbed cores.

The excellent condition of the soil after 4 years of grazing is further attested by the fact that loosening the surface soil did not increase subsequent yields of forage (table 7 ), and indeed decreased yields over the first $\mathbf{4 0}$ days following treatment, probably as a result of damage to the root system. 
The higher overall yields obtained in the second cutting are explained by more favorable rainfall during this period. Soil cores taken in the tilled plots of Pangola grass 90 days after treatment showed that the soil had regained its original physical condition with a bulk density of 1.02 and 13.6 percent of the pores drained at $60 \mathrm{~cm}$. of tension. All three grasses responded strongly to fertilization at both cuttings, whether the soil was loosened or not.

TABLE 7.-The effect of loosening the surface soil mechanically and of fertilization on subsequent yields (pounds per acre) of green forage with 9 grasses following 4 years of intensive grazing at Orocovis ${ }^{2}$

\begin{tabular}{|c|c|c|c|c|c|}
\hline \multirow{2}{*}{ Grass } & \multirow{2}{*}{$\begin{array}{l}\text { 14-1-10 fertilizer } \\
\text { applied per acre } \\
\text { yearly }\end{array}$} & \multicolumn{2}{|c|}{$\begin{array}{l}\text { First cutting }-40 \text { days after } \\
\text { applying treatment }\end{array}$} & \multicolumn{2}{|c|}{$\begin{array}{l}\text { Second cutting - } 50 \text { days after } \\
\text { first cutting }\end{array}$} \\
\hline & & Soil loosened & $\begin{array}{l}\text { Undisturbed } \\
\text { soil }\end{array}$ & Soil loosened & $\begin{array}{l}\text { Undisturbed } \\
\text { soil }\end{array}$ \\
\hline Pangola & $\begin{array}{l}0 \\
1 \text { ton }\end{array}$ & $\begin{array}{l}2,700 \\
4,700\end{array}$ & $\begin{array}{l}3,500 \\
6.900\end{array}$ & $\begin{array}{r}8,300 \\
16,400\end{array}$ & $\begin{array}{r}8,500 \\
19,800\end{array}$ \\
\hline Average & & 3,700 & 5,200 & 12,350 & 14,150 \\
\hline Guinea & $\begin{array}{l}0 \\
1 \text { ton }\end{array}$ & $\begin{array}{l}2,000 \\
3,800\end{array}$ & $\begin{array}{l}2,700 \\
4,000\end{array}$ & $\begin{array}{r}8,600 \\
13,800\end{array}$ & $\begin{array}{r}7,200 \\
16,200\end{array}$ \\
\hline \multirow[t]{2}{*}{ Average } & & 2,900 & 3,350 & 11,200 & 11,700 \\
\hline & $\begin{array}{l}0 \\
1 \text { ton }\end{array}$ & $\begin{array}{l}3,600 \\
4,600\end{array}$ & $\begin{array}{l}4,200 \\
6,000\end{array}$ & $\begin{array}{r}8,000 \\
12,800\end{array}$ & $\begin{array}{r}9,800 \\
14,000\end{array}$ \\
\hline Average & & 4,100 & 5,100 & 10,400 & 11,900 \\
\hline
\end{tabular}

1 By loosening to a depth of 4 in. with a pick without turning the sod. With Pangola grass all the area was worked; with Guinea and Napier grasses only soil between clumps was loosened.

${ }^{2}$ All values are averages of 4 replications.

The following tabulation of average daily gains in weight (pounds) for 18 native and native $\times$ Holstein bulls grazed for a full year in 1962 indicates that it is advisable to sell cattle of this type for slaughter when they attain a weight of 800 to 900 pounds, since daily gains drop off sharply beyond this point:

Weight of bulls (pounds)
$\begin{aligned} & 400-500 \\ & 500-600 \\ & 600-700 \\ & 700-800 \\ & 800-900 \\ & 900-1,000\end{aligned}$

Average daily gains per head

1.9

2.1

1.7

1.6

1.3 
Table 8 compares the productivity of Pangola, Guinea, and Napier grass pastures in this experiment on steep mountain slopes with yields obtained by Caro, Vicente, and Burleigh (4) in grazing experiments with these same grasses under similar management on level, irrigated lands on the South Coast. In both cases only yields obtained during the year when bulls were used are presented in order to have a similar basis of comparison.

Just as high yields were produced by Pangola, Guinea, and Napier grass pastures in the steep mountains as on level, expensive, irrigated lands for which there are many more profitable uses.

The data presented in this paper show that intensively managed, wellfertilized Pangola, Guinea, and Napier grass pastures can produce similar, sustained, very high yields of beef on steep slopes in the Humid Mountain

TABLE 8.-Productivity of well-fertilized, similarly managed Pangola-, Guinea-, and Napier-grass pastures on steep mountain slopes at Orocovis and on level irrigated lands near Santa Isabel (4)

\begin{tabular}{ll|rr|rr}
\hline \multirow{2}{*}{ Grass } & \multicolumn{3}{|c|}{ Gain in weight (pounds) per acre yearly forL } \\
\cline { 3 - 5 } & \multicolumn{2}{|c|}{ Mountain Region } & \multicolumn{2}{|c}{ Irrigated South Coast } \\
\hline Pangola & 1,262 & $(3.0)$ & 1,063 & $(2.6)$ \\
Guinea & 1,389 & $(3.2)$ & 1,292 & $(3.3)$ \\
Napier & 1,138 & $(2.9)$ & 1,327 & $(3.1)$ \\
& & 1,263 & $(3.1)$ & 1,227 & $(3.0)$ \\
\hline
\end{tabular}

1 Numbers in parentheses show carrying capacity in terms of 600 -lb. steers per acre.

Region of Puerto Rico and that Para grass and molassesgrass pastures are inferior under these conditions. The high productivity of Pangola, Guinea, and Napier grass pastures in the Mountain Region has recently been confirmed on a commercial beef farm near Cidra where pastures of these three grasses, managed as described in this paper, carry over 2 steels per acre and produce about 1,000 pounds of beef per acre yearly.

\section{SUMMARY}

The productivity, in terms of carrying capacity and of beef yields, of intensively managed, well-fertilized pastures of five grasses on steep slopes in the Mountain Region of Puerto Rico with annual rainfall of 63 inches, was determined.

Pangola, Guinea, and Napier grass pastures produced similar high yields, averaging 1,058 pounds of weight gain and 7,500 pounds of total digestible nutrients, equivalent to a carrying capacity of 2.4600 -pound steers per acre yearly over a 4-year period. The young cattle grazed for periods of a 
full year averaged 1.3 pounds of weight gain daily. No weeding was necessary and there was no problem with "manure spots" in these pastures receiving 1 ton of 14-4-10 fertilizer per acre yearly in four equal applications. There was little compaction of the soil by trampling, and loosening the surface soil after 4 years of intensive grazing did not increase yields of any of these grasses.

Quality of the Pangola, Guinea, and Napier grass forage was in all cases excellent and varied little with season of the year or with grass species. Crude-protein content of samples obtained throughout the year by simulated grazing averaged 18.1 percent, phosphorus 0.22 , lignin 8.1, and calcium 0.62 percent for Guinea and 0.32 percent for Napier and Pangola grasses.

Para grass and molassesgrass pastures were definitely inferior to Pangola, Guinea, and Napier grasses, producing only 636 pounds of weight gain, and 5,030 pounds of total digestible nutrients per acre yearly.

\section{RESUMEN}

Durante un período de 4 años se determinó la producibilidad de cinco yerbas, en términos de aumento en peso en el ganado y capacidad para el pastoreo. Estas yerbas estuvieron adecuadamente abonadas y bajo un cultivo intensivo en terrenos empinados de la región montañosa de Puerto Rico, donde la precipitación alcanzó un promedio de 63 pulgadas anualmente.

Los resultados fucron similares en cuanto a los pastos de las yerbas Pangola, Guinea y Napier, los cuales produjeron en promedio 1,058 libras de aumento en el peso del ganado y 7,500 libras de nutrimentos digeribles por acre anualmente. Esto equivale a una capacidad para el pastoreo de 2.4 novillos de 600 libras de peso por acre.

El ganado joven que se usó en este experimento y que se mantuvo pastando durante períodos de un año aumentó 1.3 libras por día en promedio. No fué necesario controlar los yerbajos, ni surgió el problema relacionado con la concentración de las heces en estos pastos los cuales fueron abonados cuatro veces al año con 500 libras por cuerda de abono 14-4-10 (1 tonelada por cuerda anualmente). Hubo, además, muy poca compactación del suelo causada por el pisoteo del ganado.

Las tres yerbas produjeron un forraje de excelente calidad, la cuál varió poco a través del año. Las muestras tomadas periódicamente durante todo el año tuvieron en promedio un contenido de 18.1 por ciento de proteína, 0.22 de fósforo, 8.1 de lignina, y 0.62 de calcio en el caso de la yerba Guinea y 0.32 en el de las yerbas Pangola y Napier.

Los pastos de las yerbas Para y melao fueron marcadamente inferiores a los de las yerbas Pangola, Guinea y Napier, pues sólo produjeron 636 
libras de aumento en el peso del ganado y 5,030 libras de nutrimentos digeribles por acre anualmente.

\section{LITERATURE CITED}

1. Anonymous, Report on Pasture and Range Research Techniques, Joint Committee of ASA, ASAP, ADSA, and ASRM, Agron. J. 44(1): 39-50, 1952.

2. - Nutrient Requirements of Domestic Animals No. 4, Beef Cattle Report of the Committee on Animal Nutritionl, National Academy of Sciences, National Research Council, Washington, D.C., 1958.

3. Caro-Costas, R., and Vicente-Chandler, J., Effect of fertilization on carrying capacity and beef produced by Napier grass pastures, Agron. J. $58(3)$ : 204-5, 1961.

4. Caro-Costas, R., Vicente-Chandler, J., and Burleigh, C., Beef production and carrying capacity of heavily fertilized, irrigated Guinea, Napier, and Pangola grass pastures on the semiarid south coast of Puerto Rico, J. Agr. Univ. P.R. 45(1): 32-6, 1961.

5. Rivera-Brenes, L., Colón-Torres, E., Gelpí, F., and Torres-Más, J., Influence of nitrogen fertilizer on Guinea grass yield and carrying capacity in Lajas Valley, J. Agr. Univ. P.R. 42(4): 239-47, 1958.

6. Rivera-Brenes, L., Marchán, F. J., and Cabrer, J. I., The utilization of grasses, legumes, and other forage crops for cattle feeding in Puerto Rico, J. Agr. Univ. P.R., S1 (2): 180-9, 1947; 8S(3): 85-97, 1949; \$6(2): 108-14, 1952.

7. Vicente-Chandler, J., Pearson, R. W., Caro-Costas, R., Abruña, F., Figarella, J., and Silva, S., The Intensive Management of the Major Forages of Puerto Rico, Tech. B. 187, Agricultural Experiment Station, Univ. P.R. In press. 